\title{
Giardia and Cryptosporidium in Pristine Protected Catchments in Central Eastern Australia
}

We report the first confirmed records of the pathogenic protozoa Giardia lamblia and Cryptosporidium parvum from small remote streams in pristine protected areas in Australia, beyond the reach of urban or agricultural contamination.

\section{INTRODUCTION}

Giardia lamblia and Cryptosporidium parvum are unicellular protozoa which can survive for an extended period outside their animal hosts, as cysts or oocysts, respectively, in soils or water (1). They are a significant cause of severe gastrointestinal disease; are widespread in developing nations where watercourses commonly suffer human faecal contamination; and are a major cause of travellers' diarrhoea (2). They are also widespread in the developed nations of Europe, North America and South Africa, even in small streams in protected catchments (3-10).

Their dispersal mechanism has been controversial. In North America it was ascribed initially to native mammals; later, to humans (11-13). It remains unresolved, because the organisms were already widespread in that continent long before techniques were developed to detect their (oo)cysts in waterbodies, at concentrations around $10^{-2} \mathrm{~g}^{-1}$, rather than in animal faeces at around $10^{8} \mathrm{~g}^{-1}(1,3-10)$.

Australia provides a unique opportunity to examine their distribution and dispersal. It is remote from other continents, and has a relatively high standard of public health and effective protection of drinking-water catchments. In Australia, Giardia and Cryptosporidium are widespread in watercourses subject to urban or agricultural contamination (14). Clinical cases of giardiasis or cryptosporidiosis have been recorded for many decades (1), but generally in individuals who have travelled overseas. There have been very few outbreaks of giardiasis or cryptosporidiosis in Australia, all associated with young children and their parents and carers, and all ascribed to direct faecal-oral or localized groundwater transmission (15-17). During 1998, the municipal water supply for Sydney, Australia's largest city, was threatened by Cryptosporidium contamination, forcing over 3 million people, a sixth of the nation's population, to boil drinking water for several weeks (18).

Unlike in North America and New Zealand, where remote areas have been screened for the presence of (oo)cysts $(12,19)$ the distribution of Giardia and Cryptosporidium in undisturbed water catchments in Australia remains unknown. Whilst humaninfective Giardia cysts have been isolated from native fauna in Australia (20), there have been no rigorous analyses for presence or absence of Giardia or Cryptosporidium (oo)cysts in pristine watercourses. Relatively few Australian watercourses are completely free from human contamination (21). Here, we identified a set of rivers whose entire catchments are included in longstanding national parks upstream of all human infrastructure and with no feral stock; and sampled a series of tributary streams, successively smaller and closer to springs and sources, and with fewer opportunities for potential contamination even by occasional backcountry hikers.

\section{MATERIALS AND METHODS}

We sampled 10 rivers in 7 national parks in the Central Eastern Rainforest Reserve Australia World Heritage Area (CERRA WHA), between $28^{\circ} 17^{\prime} 00^{\prime \prime}$ and $29^{\circ} 31^{\circ} 17^{\prime} ' \mathrm{~S}$ and $152^{\circ} 18^{\prime}$ $42^{\prime}$ ' and $153^{\circ} 43^{\prime} 36^{\prime}$ ' E. Samples were taken between January and May 1998. Stream characteristics were as follows: flow velocity $0.5-2.3 \mathrm{~m} \mathrm{~s}^{-1}$, turbidity 1-2 NTU, mean temperature $18.5^{\circ} \mathrm{C}$, pH 5.5-8.0, mean $\mathrm{PO}_{4}^{3-} 0.034 \mathrm{mg} \mathrm{L}{ }^{-1}, \mathrm{NO}_{2}^{-}+\mathrm{NO}_{3}^{-} 0.12$ $\mathrm{mg} \mathrm{L}^{-1}, \mathrm{NH}_{4}^{+} 0.005 \mathrm{mg} \mathrm{L}^{-1}$.

Each watercourse was sampled by direct micropore filtration of 100-140 L on site, using specially-designed portable batterypowered apparatus carried on foot. We used 2 different filtration techniques. In the first, we pumped 100-140 L samples, in 20 -L subsamples, through separate flat circular Sartorius ${ }^{\circledR}$ nitrocellulose membrane filters of $3 \mu \mathrm{m}$ pore size and $142 \mathrm{~mm}$ diameter; a total filter area of $100 \times 10^{3} \mathrm{~mm}^{2}$. The filters were preceded by $10 \mu \mathrm{m}$ Gelman ${ }^{\circledR}$ prefilters. In the second, we filtered 140 L samples through Gelman ${ }^{\circledR}$ Envirocheck ${ }^{\circledR}$ folded-cartridge polyethersulfone membranes of $1 \mu \mathrm{m}$ pore size, with an effective filtration area of $130 \times 10^{3} \mathrm{~mm}^{2}$. Up to 3 cartridges were needed for each sample depending on stream turbidity. All filters and prefilters were kept on ice after use, and treated within 72 hrs. Giardia cysts are oval, 8-12 $\mu \mathrm{m}$ long and 7-10 $\mu \mathrm{m}$ wide. Cryptosporidium oocysts are spherical, $4-6 \mu \mathrm{m}$ in diameter. The $1 \mu \mathrm{m}$ Envirocheck ${ }^{\circledR}$ cartridges trap both. The $3 \mu \mathrm{m}$ flat filters trap Giardia cysts and also trap most Cryptosporidium oocysts. A few of the smaller Cryptosporidium oocysts may pass through the $3 \mu \mathrm{m}$ flat filter. All sites were therefore also sampled using the Envirocheck ${ }^{\circledR}$ cartridges. Positive records of Cryptosporidium oocysts are of course equally valid for both filtration types.

Analytical protocols were based on an amalgam of methods from previous published studies, as below, and coincide closely with US EPA Standard Method 1622 (5, 22-26), which was adopted shortly after our samples were analyzed. Flat filters and prefilters were scraped and washed 3-4 times with $1 \%$ polyoxyethylenesorbitan monooleate (Sigma-Aldrich $\AA$ Tween $80 \AA$ ). Cylindrical filters were shaken twice for $10 \mathrm{~min}$ in $240 \mathrm{ml}$ Gelman ${ }^{\circledR}$ elution buffer ( $8 \mathrm{~g} \mathrm{NaCl}, 0.2 \mathrm{~g} \mathrm{KCl}, 0.2 \mathrm{~g} \mathrm{KH}_{2} \mathrm{PO}_{4}$, $2.9 \mathrm{~g}$ hydrated $\mathrm{Na}_{2} \mathrm{HPO}_{4}, 0.1 \mathrm{~g}$ sodium lauryl sulfate, $3 \mu \mathrm{l}$ Tween 80, $150 \mu \mathrm{l}$ Sigma ${ }^{\circledR}$ Antifoam B, 1.0 L deionized distilled water, adjusted to $\mathrm{pH} 7.4$ ). All samples were centrifuged at $3000 \mathrm{x}$ $\mathrm{g}$ for $10 \mathrm{~min}$, resuspended and purified using a percoll-sucrose gradient.

For purification, samples were centrifuged in $250 \mathrm{ml}$ tubes at $3000 \mathrm{x}$ g for $10 \mathrm{~min}$ using a refrigerated fixed-angle centrifuge; resuspended in phosphate buffered saline (PBS) at pH 7.4 with $0.1 \%$ dodecyl sulfate and $0.1 \%$ Tween 80 ; centrifuged down to $10 \mathrm{ml}$; resuspended in $5 \mathrm{ml}$ PBS underlayered with percoll-sucrose (SG 1.5); and centrifuged at $1050 \mathrm{x}$ g for $10 \mathrm{~min}$ in a swinging-bucket rotor. The upper aqueous layer and percoll-su- 
crose interface were centrifuged to a final pellet and stored at $4^{\circ} \mathrm{C}$.

Purified pellets were stained with Meridian Diagnostics ${ }^{\circledR}$ Merifluor ${ }^{\circledR}$ fluorescein isothiocyanate (FITC)-labelled monoclonal antibodies specific to Cryptosporidium and Giardia epitopes, and examined by epifluorescent microscopy using a Zeiss ${ }^{\circledR}$ Axioscop ${ }^{\circledR}$, with an excitation wavelength of 450-490 $\mathrm{nm}$, a barrier filter of 510-520 nm, $400 \times$ magnification and a Zeiss ZVS-47DEC digital camera. Bright green fluorescent bodies of appropriate dimensions were treated initially as presumptive (oo)cysts. All presumptive (oo)cysts were examined further using differential interference contrast (D.I.C.) microscopy. Any which demonstrated atypical external or internal morphological characteristics were removed from counts.

Bench-scale recovery rates were determined by analysing samples spiked with known concentrations of Giardia and Cryptosporidium (oo)cysts measured with a haemocytometer (26). Recovery rates were $53 \pm 5.5 \%$ for the flat filter technique, similar to those for previous studies; and $64 \pm 4 \%$ for Gelman ${ }^{\circledR}$ Envirocheck ${ }^{\circledR}$ cylindrical filters.

For each sample, successive $1.5 \mu \mathrm{g}$ slide wells of the stained purified pellet were examined, until either $i$ ) both Giardia cysts and Cryptosporidium oocysts were detected; $i$ i) 20 wells were counted; or iii) the entire pellet was used. Purified pellets ranged in wet-weight from $0.03-0.13 \mathrm{mg}$ per $100 \mathrm{~L}$ sample. A total of $2081.5 \mu \mathrm{g}$ slide wells were counted (Table 1). On average, over $40 \%$ of each $100 \mathrm{~L}$ sample was examined completely.

\section{RESULTS}

Giardia cysts and/or Cryptosporidium oocysts were found in every stream, no matter how small, remote and pristine, and how close to the source (Table 1). Overall mean densities were 3.4 Giardia cysts and 1.8 Cryptosporidium oocysts per 100 L. Of the 208 slide wells counted, 2 contained 2 Giardia cysts, 15 contained 1, and 191 contained none (Table 1). Similarly, 10 contained 1 Cryptosporidium oocyst and 198 contained none. The frequencies of cysts and oocysts are slightly higher in the national parks of northernmost NSW (10/64, 4/64, respectively), than in those of southeast Qld $(6 / 84,4 / 84)$ and mid-north NSW $(3 / 60,1 / 60)$. The difference is significant at $\mathrm{p}<0.05$ for Giardia but not Cryptosporidium.

\section{DISCUSSION}

These are the first published records of Giardia lamblia and Cryptosporidium parvum from surface waters in pristine pro- tected areas in Australia. Indeed, they are the first records from such small protected watercourses worldwide. The closest equivalent study in North America found that these protozoa were not present in the headwaters of protected montane catchments, though they were further downstream (3). Cyst concentrations detected in the CERRA WHA are as high as those in protected areas in North America (3-10).

The watercourses tested here are as well or better protected from contamination by Giardia and Cryptosporidium as any others worldwide, except perhaps for those in remote oceanic or subantarctic islands. The Australian continent has historically been free from many of the world's otherwise widespread waterborne pathogens (20); and within Australia, there are very few water catchments which are equally undisturbed. Most protected areas either have roads and tracks, a history of logging, grazing or horse pasture, or feral dogs, cats, pigs, cattle, goats, horses, and donkeys, which routinely carry Giardia and Cryptosporidium (27-31). Hence, the results reported here indicate that Giardia and Cryptosporidium are probably present in every suitable habitat worldwide.

The mechanism by which they have reached these protected streams is likely to involve several factors. Whilst Giardia cysts and Cryptosporidium oocysts are robust and could potentially be carried as high-altitude atmospheric particles, the concentrations reported here are orders of magnitude too high for this to be the only source, and indicate a contaminated faecal input directly within the catchments concerned. Humans are an unlikely vector in this case, even though $1-3 \%$ of the human population in this region carries Giardia asymptomatically (Wild, C. and Vogt, S., unpubl. data), because the sampling sites were specifically selected to exclude them. The most likely mechanism is that native marsupials or possibly feral cats, both of which can carry Giardia $(11,20)$, may have transmitted it from adjacent catchments with domestic stock, or from areas contaminated by humans further downstream in the same catchments. A wide variety of small- to medium-sized marsupials and other mammals are present in the study areas. Birds are another possible vector, but avian isolates may not be cross-infective to mammals (32, 33).

An expert inquiry into the 1998 Sydney water contamination event (18) identified several possible sources of Cryptosporidium, some pre- and some post-treatment. The results reported here indicate that most or all of the catchments for municipal water supply in Australia, and indeed worldwide, almost certainly contain Giardia cysts and Cryptosporidium oocysts at low concentrations. From a public health perspective the issue is now one of risk management. Broadly, treatment systems with

Table 1. Abundance of Giardia cysts and Cryptosporidium oocysts in water samples isolated from different watercourses at test sites.

\begin{tabular}{llccc}
$\begin{array}{l}\text { National } \\
\text { Park }\end{array}$ & River & $\begin{array}{c}\text { Number of } \\
1.5 \mu \text { wells } \\
\text { counted for } \\
\text { this sample }\end{array}$ & $\begin{array}{c}\text { Total } \\
\text { Giardia } \\
\text { cysts in } \\
\text { entire sample }\end{array}$ & $\begin{array}{c}\text { Total } \\
\text { Cryptosporidium } \\
\text { oocysts in } \\
\text { entire sample }\end{array}$ \\
\hline Lamington & Canungra & 8 & 1 & 2 \\
Lamington & Canungra & 16 & 1 & 0 \\
Lamington & Canungra & 16 & 1 & 0 \\
Lamington & Canungra & 12 & 1 & 0 \\
Lamington & Purragulli & 16 & 1 & 1 \\
Lamington & Nixon & 16 & 4 & 1 \\
Border Ranges & Brindle & 8 & 2 & 1 \\
Toonumbah & Iron Pot & 20 & 3 & 1 \\
Mount Warning & Korrumbyn & 16 & 1 & 1 \\
Whian Whian & Minyon & 20 & 1 & 0 \\
Gibraltar Range & Surveyor & 20 & 2 & 1 \\
Gibraltar Range & Dandahra & 20 & 0 & \\
Washpool & Coombadjha & 20 & & \\
& & & &
\end{tabular}


flocculation or filtration steps remove protozoan cysts, whereas those with chlorination only do not (5-10).

Large holding dams with multi-day residence times may allow cysts to settle to bottom sediments; but these can be resuspended during storm floods, and there have been several major instances of cryptosporidiosis and associated gastrointestinal infection through ingesting water from lakes used for recreation $(34,35)$. The costs of retrofitting or replacing water treatment systems which do not currently remove protozoan cysts must therefore be balanced against the likely concentrations of cysts and oocysts in the catchment; the likelihood that they are viable and human-infective; and the likelihood that they will pass undamaged through existing treatment processes. Viability is testable using the 4,6-diamino-2-phenylindole (DAPI) method, and reverse-transcription PCR respectively as applied by Johnson et al., Mayer and Palmer, Stinear et al., and Kaucner and Stinear (36-39).
Giardia and Cryptosporidium are already significant threats to human health worldwide (40), and likely to become much more so in future. Without basic information on distribution and concentration of both protozoa, public health responses are likely to be hampered and ineffective. Now that field sampling techniques for remote areas are available, it is feasible to compile for empirical data for Australian water catchments. Whether this actually occurs in practice will depend on funding priorities by public health and water-supply authorities.

\section{References}

1. Adam, D.A. 1991. The biology of Giardia spp. Microbiol. Rev. 55, 706-732.

2. Sterling, C.R., Seegar, K. and Sinclair, N.A. 1986. Cryptosporidium as a causative agent for traveler's diarrhoea. J. Inf. Diseases 153, 380-381.

3. Ong, G., Moorehead, W., Ross, A. and Isaac-Renton, J. 1996. Studies of Giardia spp. and Cryptosporidium spp. in two adjacent watersheds. Appl. Environ. Microbiol. 62, 2798-2805.

4. Ongerth, J.E., Hunter, G.D. and DeWalle, F.B. 1995. Watershed use and Giardia cyst prevalence. Water Res. 29, 1295-1299.

5. LeChevallier, M.W., Norton, W.D., Siegel, J.E. and Abbaszadegan, M. 1995. Evaluation of the immunofluorescence procedure for the detection of Giardia cysts and Cryptosporidium oocysts in water. Appl. Environ. Microbiol. 61, 690-697.

6. Lisle, J.T. and Rose, J.B. 1995. Cryptosporidium contamination of water in the USA and UK: A mini-review. Aqua 44, 103-117.

7. Kfir, R., Hilner, C., duPreez, M. and Bateman, B. 1995. Studies on the prevalence of Giardia cysts and Cryptosporidium oocysts in South African water. Water Sci. Tech. $31,435-438$.

8. Wallis, P.M., Erlandsen, S.L., Isaac-Renton, J.L., Olson, M.E., Robertson, W.J. and van Keulen, H. 1996. Prevalence of Giardia cysts and Cryptosporidium oocysts and characterisation of Giardia spp. isolated from drinking water in Canada. Appl. Environ. Microbiol. 62, 2789-2797.

9. Edzwald, J.K. and Kelley, M.B. 1998. Control of Cryptosporidium: From reservoirs to clarifiers to filters. Water Sci. Tech. 37, 1-8

10. Fayer, R., Graczyk, T.K., Lewis, E.J., Trout, J.M. and Austin, J. 1998. Survival of infectious Cryptosporidium parvum oocysts in seawater and Eastern Oysters (Crassostrea virginica) in the Chesapeake Bay. Appl. Environ. Microbiol. 64, 1070-1074.

11. Davies, R.B. and Hibler, C.P. 1979. Waterborne Transmission of Giardiasis. Publication 104. US Environmental Protection Agency, Washington DC.

12. Istre, G.R., Dunlop, T.S., Gaspard, G.B. and Hopkins, R.S. 1984. Waterborne giardiasis at a mountain resort: Evidence for acquired immunity. Am. J. Publ. Health 74, 602 sis at

13. Isaac-Renton, J.L., Moricz, M.M. and Proctor, E.M. 1987. A Giardia survey of furbearing water mammals in British Columbia, Canada. J. Env. Health 50, 80-83.

14. Thurman, R., Faulkner, B., Veal, D., Cramer, G. and Meiklejohn, M. 1998. Water quality in rural Australia. J. Appl. Microbiol. 84, 627-632.

15. Thompson, S.C. 1994. Giardia lamblia in children and child sitting: A review of the literature. J. Paediatr. Child Health 30, 202-209.

16. Forshaw, D., Palmer, D.G., Halse, S.A., Hopkins, R.M. and Thompson, R.C.A. 1992 Giardia in straw necked ibis (Threskiornis spinicollis) in Western Australia. Vet. Rec 131, 267-268

17. Kay, R., Barnes, G.L. and Townley, R.R.W. 1977. Giardia lamblia infestation in 154 children. Aust. Paediat. J. 13, 98-104.

18. Sinclair, M. 1998. Protozoa in Sydney. Health Stream 11, 1-11.

19. Brown, T.J., Hastie, P.J., Kelly, P.J., Van Duivenboden, T., Ainge, J., Jones, N., Walker, N., Till, D.G., Sillars, H. and Lemmon, F. 1991. Presence and distribution of Giardia cysts in New Zealand waters. N. Z. J. Mar. Freshw. Res. 26, 279-282

20. Buckley, R.C., Clough, E. and Vogt, S. 1997. Immunologically confirmed human-infective Giardia from two marsupials. Ambio 26, 554-555.

21. Nix, H., Stein, J. and Hutchison, M. 1996. A national database for catchment and flow disturbance. In: Australia's Wild Rivers, Margerum, R. and Hudson, B. (eds). QUT, disturbance. In:

22. Ho, B.S.W., Tam, T.Y., Hutton, P. and Yam, W.C. 1995. Detection and enumeration of Giardia cysts in river waters of Hong Kong by flocculation-percoll/sucrose gradient-immunofluorescence method. Water Sci. Tech. 31, 431-434.

23. Bielec, L., Boisvert, T.C. and Jackson, S.G. 1996. Modified procedure for recovery of Giardia cysts from diverse water sources. Appl. Microbiol. 22, 21-25. (Letter.)

24. Shepard, K.M. and Wyn-Jones, A.P. 1996. An evaluation of methods for the simultaneous detection of Giardia cysts and Cryptosporidium oocysts from water. Appl. Environ. Microbiol. 62, 1317-1322.

25. Gelman Sciences Inc. 1997. Analysis of Envirocheck sampling capsule versus traditional string wound cartridges for collection and recovery of Cryptosporidium. Technical Information Sheet \# 32972, Gelman Sciences Pty. Ltd., Sydney.

26. USEPA, Draft Methods 1622. 1997. Cryptosporidium in Water by Filtration/IMS/FA. EPA 821-R-97-021. U.S. Environmental Protection Agency, Washington, DC

27. Fewtrell, L. and Delahunty, A. 1995. The incidence of cryptosporidiosis with other gastro-intestinal illnesses in Blackpool, Wyre and Fylde. J. Chart. Inst. Water Environ. gastro-intestinal ill

28. Bukhari, Z. and Smith, H.V. 1995. Effect of three concentration techniques on viability of Cryptosporidium parvum recovered from bovine feces. J. Clin. Microbiol. 33, 2592-2595.
29. Ruest, N., Couture, Y. and Faubert, G. 1995. Pathogenic potential of Giardia infections in cattle. Parasitol. Today 11, 184

30. Milstein, T.C. and Goldsmid, J.M. 1995. The presence of Giardia and other zoonotic parasites of urban dogs in Hobart, Tasmania. Aust. Vet. J. 72, 154

1. Atwill, E.R., Sweitzer, R.A., Pereira, M.G., Gardener, I.A., van Vuren, D. and Boyce, W.M. 1997. Prevalence of and associated risk factor for shedding Cryptosporidium parvum oocysts and Giardia cysts within feral pig populations in California. Appl. Environ. Microbiol. 63, 3946-3949.

32. Awadelkariem, F.M., Warhurst, D.C. and McDonald, V. 1995. Differentiation between human and animal strains of Cryptosporidium parvum using isoenzyme typing. Parasitol. 110, 129-132.

33. Graczyk, T.K., Cranfield, M.R., Fayer, R. and Anderson, M.S. 1996. Viability and infectivity of Crypotosporidium parvum oocysts are retained upon intestinal passage through a refractory avian host. Appl. Environ. Microbiol. 62, 3234-3237.

34. Craun, C.F., Hubbs, S.A., Frost, F., Calderon, R.L. and Via, S.H. 1998. Waterborne outbreaks of cryptosporidiosis. J. Am. Water Works Ass.90,81-91.

35. Kramer, M.H Sorhage, F. E. Goldstein, S.T., Dalley, E. Wahlquist, S.P and Herwaldt, B.L. 1998. First reported outbreak of cryptosporidiosis associated with a recreational B.L. 1998. First reported outbreak
lake. Clin. Inf. Disease 26, 27-33.

36. Johnson, D.W., Pieniazek, N.J., Griffin, D.W., Misener, L. and Rose, J.B. 1995. DeJohnson, D.W., Pieniazek, N.J., Griffin, D.W., Misener, L. and Rose, J.B. 1995. De-
velopment of a PCR protocol for sensitive detection of Cryptosporidium oocysts in water samples. Appl. Environ. Microbiol. 61, 3849-3855.

37. Mayer, C.L. and Palmer, C.J. 1996. Evaluation of PCR, nested PCR and fluorescent antibodies for detection of Giardia and Cryptosporidium species in wastewater. Appl. Environ. Microbiol. 62, 2081-2085.

38. Stinear, T., Matusan, A., Hines, K. and Sandery, M. 1997. Detection of a single viable Cryptosporidium parvum oocyst in environmental water concentrates by reverse transcription-PCR. Appl. Environ. Microbiol. 63, 815.

39. Kaucner, C. and Stinear, T. 1998. Sensitive and rapid detection of viable Giardia cysts and Cryptosporidium oocysts in large volume water samples with wound fibreglass cartridge filters and reverse transcription-PCR. Appl. Environ. Microbiol. 64, 17431749 .

40. Mackenzie, W.R., Hoxie, N.J., Proctor, M.E., Gradus, M.S., Blair, K.A., Peterson, D.E., Kazmierczak, J.J., Addiss, D.G., Fox, K.R., Rose, J.B. and Davis, J.P. 1994. A massive outbreak in Milwaukee of Cryptosporidium infection transmitted through public water supply. New Engl. J. Med. 331, 161-167.

41. This work was supported by the Queensland Parks \& Wildlife Service; NSW National Parks \& Wildlife Service; Gelman Science Inc. and Sartorius Inc.

42. First submitted 19 Febr. 2001. Accepted for publication after revision 7 March 2002

\begin{abstract}
Ralf Buckley is Professor of Ecotourism in the School of Environmental and Applied Sciences (EAS) at Griffith University, and Director of the International Centre for Ecotourism Research (ICER). An ecologist by training, most of his professional career has been in environmental management and impact assessment, with a particular focus on the tourism sector during the past decade.
\end{abstract}

\begin{abstract}
Wiebke Warnken is an environmental microbiologist who has specialized in detection of visitor impacts on water quality in protected areas. During this study she was a Research Fellow at ICER and a lecturer at EAS. She is currently based in Germany.
\end{abstract}

Their address: ICER, Griffith University, PMB 50, Gold Coast QId, 9726, Australia.

E-mail: r.buckley@mailbox.gu.edu.au 